\title{
Teori Kewirausahaan Kewaspadaan: Eksploitasi Keseimbangan Penawaran dan Permintaan
}

\author{
Agung Purnomo \\ Program Studi Kewirausahaan \\ Universitas Bina Nusantara \\ agung.purnomo@binus.ac.id
}

Kajian kewirausahaan di nusantara kian tumbuh dan berkembang (Purnomo et al., 2019). Entrepreneurship atau kewirausahaan adalah proses kegiatan seorang wirausahawan sebagai orang memulai dan mengelola bisnis dengan mengeksploitasi ide-ide bisnis menjadi peluang yang menguntungkan atau memberi manfaat (Purnomo et al., 2020). Untuk memahami dan mengembangkan pengetahuan kewirausahaan, para ilmuwan melakukan studi dan mengembangkan beberapa teori kewirausahaan.

Salah satu teori kewirausahaan yang berkembang adalah teori kewirausahaan kewaspadaan (the alertness theory of entrepreneurship). Teori kewirausahaan kewaspadaan digagas oleh Israel M. Kirzner, seorang ekonom Inggris-Amerika dan profesor emeritus di Universitas New York, Amerika. Kirzner dikaitkan dengan sekolah ekonomi Austria (Austrian School of Economics). Kirzner berpendapat bahwa teori kewirausahaan kewaspadaan adalah upaya pengusaha menyeimbangkan penawaran dan permintaan dengan mendeteksi ketidaksempurnaan pasar (market imperfections) dan mengeksploitasinya. Ketidaksempurnaan pasar disebabkan oleh asimetri informasi (information asymmetry) dan rasionalitas yang terbatas (bounded rationality) (Kirzner, 1973).

Asimetri informasi mengacu pada kasus di mana pemangku kepentingan yang berbeda memiliki informasi yang berbeda-beda tentang usaha bisnis. Jika satu pemangku kepentingan menggunakan keuntungan informasi untuk mendapatkan keuntungan dari pemangku kepentingan lainnya, hal itu berarti melakukan tawarmenawar oportunistik. Rasionalitas terikat mengacu pada gagasan bahwa manusia tidak rasional secara sempurna. Ekonomi Neo-klasik dan Klasik memodelkan asumsi manusia ekonomi, dan cenderung mengabaikan rasionalitas yang terikat (Kirzner, 1973).

Perbedaan kewaspadaan kewirausahaan dapat dikaitkan dengan perbedaan dalam skema yang digunakan untuk membuat akal dalam menanggapi rangsangan baik eksternal atau internal. Perbedaan ini dalam kekayaan skema yang diaktifkan terutama sejauh mana skema mencakup atribut untuk penciptaan nilai, kekuatan 
asosiasi skema tersebut dengan stimulus tertentu dan sejauh mana pengusaha individu sengaja mempersiapkan skema untuk aktivasi (Valliere, 2013).

Kirzner berpendapat bahwa keuntungan yang didapat pengusaha dari kewirausahaan adalah imbalan atas toleransi mereka terhadap ketidakpastian karena mereka menghilangkan peluang arbitrase yaitu peluang untuk menjual suatu produk yang relevan serupa dengan penawaran harga yang lebih mahal daripada yang seorang pengusaha beli akibat implikasi oleh ketidaktahuan atau ketidakmampuan pemegang jabatan perusahaan. Pengusaha perlu waspada agar dapat melihat peluang ekonomi yang belum bisa dilihat orang lain, seperti kebutuhan akan barang atau jasa baru (Kirzner, 1973).

Peluang dipandang ada hanya karena ketidaktahuan para petahana. Jika tidak, peluang tersebut sudah akan dieksploitasi. Ketika petahana tidak mengetahui informasi kunci atau bahkan tidak menyadari apa yang tidak mereka ketahui, maka peluang untuk berwirausaha lahir. Ketidaktahuan melahirkan kesalahan yang bisa diperbaiki oleh tindakan pengusaha. Pengusaha bertindak di bawah ketidakpastian dan tidak dapat mengetahui apakah tindakannya akan menghasilkan keuntungan sampai setelah tindakan tersebut dilakukan. Jadi, pengusaha harus menerima bahwa mereka mungkin kehilangan uang atau investor mereka dari tindakan mereka jika ternyata tidak benar (Laplume \& Yeganegi, 2018).

Kirzner percaya bahwa kewirausahaan tidak bisa diajarkan. Namun, keyakinan ini telah dikritik karena riset pasar dan penemuan pelanggan dapat dengan jelas membantu mengenali jenis peluang tertentu. Tetapi mungkin ada bantahan bahwa mengetahui bahwa riset pasar diperlukan pada awalnya adalah kewirausahaan. Kirzner tidak memandang tindakan ekonomi seperti membeli sumber daya atau menciptakan produk baru sebagai kewirausahaan. Melainkan hanya tindakan kewaspadaan yang bersifat kewirausahaan (Laplume \& Yeganegi, 2018).

\section{Daftar Pustaka}

Kirzner, I. M. (1973). Competition and Entrepreneurship. University of Chicago Press. https://press.uchicago.edu/ucp/books/book/chicago/C/bo27304815.html

Laplume, A., \& Yeganegi, S. (2018). Kirzner' s Alertness Theory of Entrepreneurship. Entrepreneurship Theories.

https://entrepreneurshiptheories.blogspot.com/2017/08/kirznerianentrepreneurship.html

Purnomo, A., Sudirman, A., Hasibuan, A., Sudarso, A., Sahir, S. H., Salmiah, Mastuti, R., Chamidah, D., Koryati, T., \& Simarmata, J. (2020). Dasar-Dasar Kewirausahaan: untuk Perguruan Tinggi dan Dunia Bisnis. Yayasan Kita Menulis.

https://kitamenulis.id/2020/04/06/dasar-dasar-kewirausahaan-untuk-perguruantingi-dan-dunia-bisnis/

Purnomo, A., Usman, I., \& Asitah, N. (2019). Penelitian Kewirausahaan di Indonesia : Pemetaan Publikasi dalam Perspektif Scientometrik (1972-2019). AdBispreneur, 
4(3), 207. https://doi.org/10.24198/adbispreneur.v4i3.25021

Valliere, D. (2013). Towards a schematic theory of entrepreneurial alertness. Journal of Business Venturing, 28(3), 430-442.

https://doi.org/10.1016/j.jbusvent.2011.08.004 